\title{
JOB PERFORMANCE DAN JOB SATISFACTION WARTAWAN SEBAGAI DAMPAK JOB STRESS DI MASA PANDEMI COVID-19
}

\author{
Dian Agustina $^{1}$, Dita Oki Berliyanti ${ }^{2}$, dan Ida Ariyani ${ }^{3}$ \\ Jurusan Manajemen, Universitas Terbuka, Jakarta ${ }^{1}$ \\ Jurusan Manajemen, Universitas Trisakti, Jakarta ${ }^{2}$ \\ Jurusan Manajemen, STIE Tri Dharma Widya, Jakarta3 \\ dian.agustina@gmail.com ${ }^{\nwarrow}$,ditaoki67@gmail.com ${ }^{2}$,ida.ariyani28@gmail.com ${ }^{3}$
}

\begin{abstract}
ABSTRAK
Tujuan penelitian ini adalah untuk menganalisis pengaruh job stress terhadap job performance dan job satisfaction dengan mediasi work engagement. Penelitian ini menggunakan Job Stress sebagai variabel bebas, Job Performance dan Job Satisfaction sebagai variabel terikat, dan Work Engagement sebagai variabel mediasi. Data dikumpulkan dari 311 responden yang merupakan wartawan di media cetak dan online yang bekerja di Jakarta. Teknik pengambilan data dalam penelitian ini menggunakan purposive sampling dan instrumen penelitian menggunakan kuesioner yang dikirimkan melalui Google Form. Analisis data dilakukan dengan metode Structural Equation Model (SEM) AMOS 22.

Hasil penelitian menunjukkan terdapat pengaruh positif dan signifikan job stress terhadap work engagement tetapi berpengaruh negative terhadap job performance dan tidak signifikan terhadap job satisfaction, terdapat pengaruh positif dan signifikan work engagement terhadap job performance. Work engagement berpengaruh posisit fan terhadap job satisfaction dan job satisfaction. Hasil penelitian ini yaitu untuk dapat mempertahankan pengaruh Job Stress terhadap Job Performance dan Job Satisfaction yang dimediasi Work Engagement pada wartawan di Jakarta akibat penerapan kebijakan WFH sebagai dampak pandemi COVID-19.
\end{abstract}

Kata Kunci: Job Stress, Job Performance, Job Satisfaction, Work Engagement

\section{ABSTRACT}

This study aimed to analyze the effect of job stress on job performance and job satisfaction by mediating work engagement. This study uses Job Stress as the independent variable, Job Performance and Job Satisfaction as the dependent variables, and Work Engagement as the mediating variable. Data collection from 311 print and online media journalists in Jakarta. The data collection technique in this study used purposive sampling, and the research instrument used a questionnaire sent via Google Form. Data analysis using the Structural Equation Model (SEM) AMOS 22 method.

The results show a positive and significant effect of job stress on work engagement but negatively affects job performance and insignificant job satisfaction. Work engagement has a positive effect on job performance and job satisfaction. The results of this study are to maintain the effect of Job Stress on Job Performance and Job Satisfaction mediated by Work Engagement on

${ }^{1} \not$ Corresponding Author: Dian Agustina (dian.agustina@gmail.com) 
journalists in Jakarta due to the implementation of the WFH policy as a result of the COVID-19 pandemic.

Keywords: Job Stress, Job Performance, Job Satisfaction, Work Engagement

\section{PENDAHULUAN}

Kebijakan bekerja dari rumah atau work from home (WFH) yang diterapkan pemerintah akibat pandemi COVID-19 selama lebih dari 1,5 tahun terakhir membuat banyak karyawan stres. Fakta bahwa WFH lebih melelahkan dibandingkan bekerja normal di kantor juga dirasakan oleh wartawan. Jam kerja yang lebih panjang, miskomunikasi, kelelahan, bosan, kehilangan motivasi, produktivitas rendah, kesulitan liputan langsung di lapangan, risiko terpapar, dan kesulitan berkoordinasi dengan tim secara langsung menyebabkan stres pada wartawan. Survei global oleh John Crowley mencatat, sebanyak tiga perempat wartawan di dunia, termasuk di Indonesia, mengalami stres akibat lockdown. Dari 130 wartawan, sebanyak 77\% mengaku mengalami stres akibat kebijakan lockdown, 57\% mengatakan stres akibat lockdown telah memengaruhi produktivitas kerja, 44\% memengaruhi hubungan mereka dengan keluarga dan teman, serta 59\% merasakan tertekan dan cemas. Survei juga mencatat bahwa WFH telah memengaruhi kesehatan mental para wartawan. Bekerja dari rumah juga sangat memengaruhi kinerja, produktivitas, dan kreativitas mereka.

Job stress merupakan reaksi tubuh terhadap beban pekerjaan yang tidak sesuai dengan kemampuan yang dimiliki seorang karyawan sehingga berdampak pada fisik dan emosional. (Amin et. al., 2018; Chen et. al., 2006; Hafeez, 2018; Jehangir et. al., 2011; Muala, 2017; Ahmad 2020; Moura et. al., 2014). Menurut Najder dan Merecz-Kot (2014), job stress berdampak negatif pada job performance dan profitabilitas organisasi. Sementara itu, job performance merupakan gabungan dari berbagai kondisi, seperti perilaku, emosi, dan kualitas individu, yang dimiliki karyawan untuk mencapai tujuan organisasi. (Naveed Jabbar et. al., 2019; Ramos-Villagrasa et. al., 2019; Ryu, 2020; Wang dan Chen, 2020; (Gharib et. al., 2016; Hafeez, 2018). Salleh et. al. (2020) menyebutkan, karyawan yang mendapat beban pekerjaan tinggi dapat mengurangi job performance mereka. Job performance seorang pekerja akan buruk ketika stres lebih tinggi. Lebih lanjut, job satisfaction adalah perasaan kesenangan yang diekspresikan seorang karyawan terhadap aspek pekerjaan dan organisasi mereka. (Whitman et. al., 2010; Martins \& Proença 2014; Ramalho Luz et. al., 2018; Rizwan et. al., 2014; Yang et. al., 2021; Yalabik et. al., 2017; Rai \& Maheshwari, 2020; Abu shamaa et. al., 2016). Menurut Singh et. al. (2019), salah satu dampak psikologis job stress adalah menurunnya job satisfaction, yang dapat memicu karyawan berhenti dari pekerjaannya. Sedangkan work engagement adalah keterlibatan dan komitmen karyawan terhadap pekerjaannya untuk menciptakan kemajuan organisasi. Karyawan dengan work engagement tinggi akan berbicara positif tentang semua hal terkait organisasi. Mereka juga peduli dengan nilai dan aturan organisasi. (Amin et. al., 2018; Bakker dan Demerouti, 2008; Fontes et. al., 2019; Schaufeli, 2012; Wang dan Chen, 2020; Pollak et. al., 2017; Burke \& El-Kot, 2010).

Kebijakan WFH akibat pandemi COVID-19 menyebabkan stres sehingga menurunkan performansi wartawan karena selama bekerja dari rumah, wartawan tidak bisa melakukan peliputan dan bertemu narasumber secara langsung. Akibatnya banyak wartawan yang menulis artikel berita berdasarkan dari pernyataan atau status seseorang melalui sosial media - sebagai contoh adalah Twitter, tanpa melakukan konfirmasi kepada yang bersangkutan. Sementara itu, tingkat kepuasan wartawan terhadap pekerjaan juga turun karena beban kerja dan demand dari atasan yang datang bertubi-tubi, jaringan Internet di 
rumah tidak stabil, serta minimnya fasilitas yang menunjang pekerjaan yang disediakan kantor saat bekerja dari rumah. Sedangkan work engagement wartawan sepertinya tidak perlu diragukan lagi karena ketika mengalami job stress, wartawan tetap giat bekerja, gigih berusaha, dan bertanggung jawab terhadap pekerjaan dengan dilandasi semangat, skill, passion, keterampilan, dan profesionalitasnya dalam menyelesaikan pekerjaan.

Berdasarkan uraian latar belakang di atas, maka dilakukan penelitian untuk menganalisis apakah terdapat pengaruh di masing-masing variabel, yaitu job stress, job performance, job satisfaction, dan work engagement pada wartawan di Jakarta akibat penerapan kebijakan WFH sebagai dampak pandemi COVID-19. Tujuan penelitian ini sesuai dengan rumusan masalah yaitu untuk menganalisis pengaruh (1) job stress terhadap work engagement, (2) work engagement terhadap job performance, (3) job stress terhadap job performance, (4) job stress terhadap job satisfaction, (5) work engagement terhadap job satisfaction, (6) job stress terhadap job performance yang dimedisi work engagement, (7) job stress terhadap job satisfaction yang dimediasi work engagement.

\section{KAJIAN LITERATUR}

\section{Pengaruh job stress terhadap work engagement}

Hafeez (2018) menyebutkan bahwa job stress merupakan reaksi kritis fisik dan psikologis yang terjadi ketika syarat-syarat sebuah pekerjaan tidak sesuai dengan bakat, sumber, atau persyaratan lain yang dimiliki karyawan. Amin et. al. (2018) mengatakan, job stress merupakan respons tubuh terhadap tuntutan dan keadaan yang dihadapi para karyawan. Menurut Muala (2017), job stress adalah respons bahaya yang ditunjukkan fisik dan emosional yang terjadi ketika syarat-syarat dalam pekerjaan tidak sesuai dengan kemampuan, sumber daya, atau kebutuhan pekerja. Jehangir et. al. (2011) mendefinisikan job stress sebagai situasi yang muncul dari reaksi individu terhadap tugasnya hingga menyebabkan perubahan yang memaksa individu harus bisa mengatasi dan menyesuaikan kinerja normalnya. Job stress dapat mempengaruhi work engagement. Work engagement merupakan keadaan mental yang positif dan menyadari diri sendiri di mana seseorang merasa terhubung dengan pekerjaannya (Wang dan Chen, 2020). Menurut Fontes et. al. (2019), work engagement merupakan keadaan realisasi afektif-motivasi positif yang terkait dengan pekerjaan yang ditandai dengan dimensi kekuatan, dedikasi, dan penyerapan. Amin et. al., (2018) menyebutkan bahwa work engagement adalah proses yang berkelanjutan dan menunjukkan aspek positif dari karyawan. Work engagement diartikan sebagai konstruksi motivasi dan positif yang berhubungan dengan pekerjaan yang bercirikan semangat (vigor), dedikasi (dedication), dan absorpsi (absorption) (Schaufeli, 2012). Menurut Bakker dan Demerouti (2008), work engagement adalah keadaan di mana karyawan dengan engagement-nya memiliki tingkat energi yang tinggi dan antusias terhadap pekerjaan mereka.

Vandiya \& Etikariena (2018) dalam penelitianya menyebutkan, job stress berpengaruh negatif tapi tidak signifikan terhadap work engagement. Fontes et. al. (2019) dalam studinya menyebutkan, job stress berpengaruh negatif terhadap work engagement. Motamedzade et. al. (2019) dalam penelitiannya menemukan bahwa work engagement berpengaruh negatif pada job stress. Amin et. al. (2018) dalam penelitiannya menemukan bahwa job stress berpengaruh negatif terhadap work engagement. Coetzee \& Villiers (2010) dalam penelitiannya menemukan bahwa sumber job stress yang dirasakan karyawan berpengaruh negatif terhadap work engagement dan orientasi karier mereka. Moura et. al. (2014) dalam penelitiannya menjelaskan, job stress berpengaruh negatif terhadap work engagement. Dengan demikian hipotesis pertama penelitian ini sebagai berikut:

H1: Terdapat pengaruh negatif job stress terhadap work engagement di kalangan wartawan 


\section{Pengaruh work engagement terhadap job performance}

Naveed Jabbar et. al. (2019) menyatakan, job performance merupakan keadaan emosi yang menyenangkan atau positif yang memiliki komponen emosional, kognitif, dan perilaku. Menurut Ramos-Villagrasa et. al. (2019) job performance merupakan kriteria utama dalam manajemen sumber daya manusia. Ryu (2020) mengatakan, job performance merupakan hasil dari proses kerja, yaitu keluaran yang dicapai dalam kurun waktu tertentu oleh karyawan kepada organisasi melalui pendekatan tertentu. Job performance karyawan merupakan subjek paling kritis yang memegang peranan penting dalam pencapaian kinerja organisasi (Gharib et. al., 2016). Hafeez (2018) menyebut job performance sebagai kemampuan karyawan untuk bekerja secara efisien agar tujuan organisasi tercapai.

Wang \& Chen (2020) dalam penelitiannya menemukan, work engagement berpengaruh positif dengan job performance. Inamizu \& Makishima (2018) dalam penelitiannya menyebutkan, ada pengaruh positif antara job performance dan work engagement. Hasil penelitian Suryanthini (2020) menunjukkan, employee engagement berpengaruh positif terhadap job performance. Herliani \& Sagala (2021) dalam penelitiannya menyebutkan, terdapat pengaruh positif antara work engagement terhadap job performance. Ketika work engagement naik, job performance juga naik. Naveed Jabbar et. al. (2019) dalam penelitiannya menemukan bahwa optimisme dan work engagement berpengaruh positif pada job performance. Hipotesis pertama penelitian ini sebagai berikut: H2: Terdapat pengaruh positif work engagement terhadap job performance di kalangan wartawan

\section{Pengaruh job stress terhadap job performance}

Herliani \& Sagala (2021) dalam penelitiannya menyebutkan, jika job stress meningkat, maka job performance turun. Salleh et. al. (2020) dalam penelitiannya menemukan bahwa job stress berhubungan positif dengan job performance. Yang membuat job stress dan job performance buruk adalah pekerjaan yang terlalu banyak dan waktu menyelesaikan pekerjaan yang sangat sedikit. Ahmad (2020) dalam penelitiannya menemukan bahwa job stress berpengaruh negatif terhadap job performance. Basit \& Hassan (2017) dalam penelitiannya menyebutkan bahwa work load dan time pressure berpengaruh negatif terhadap kinerja karyawan. Hipotesis pertama penelitian ini sebagai berikut:

H3: Terdapat pengaruh negatif job stress terhadap job performance di kalangan wartawan

\section{Pengaruh job stress terhadap job satisfaction}

Rai \& Maheshwari (2020) menyebut job satisfaction sebagai cara karyawan mengembangkan persepsi tentang pekerjaan mereka dan bagaimana mereka menyukai pekerjaan tersebut. Semakin lingkungan kerja memperhatikan kebutuhan dan nilai karyawan, semakin puas karyawan dengan pekerjaan mereka (Abu shamaa et. al., 2016). Job satisfaction menurut Whitman et. al. (2010) merupakan keadaan internal yang diekspresikan seseorang terhadap pekerjaan yang sudah lama digeluti berdasarkan derajat suka dan tidak suka. Martins \& Proença (2014) mengatakan bahwa job satisfaction merupakan kumpulan perasaan atau respons afektif terhadap pekerjaan seseorang tentang aspek pekerjaan mereka dari sudut pandang berbeda.

Penelitian Rizwan et. al. (2014) menunjukkan bahwa job stress berpengaruh negatif terhadap job satisfaction. Semakin tinggi job stress yang dialami pekerja, semakin rendah job satisfaction. Jehangir et. al. (2011) dalam penelitiannya menjelaskan bahwa job stress berpengaruh negatif terhadap job performance dan job satisfaction. Orgambídez-Ramos et. al. (2014) dalam penelitiannya menyebutkan, stres berpengaruh negatif pada job 
satisfaction. Semakin rendah stres yang dirasakan karyawan, semakin tinggi job satisfaction yang dialami. Singh et. al. (2019) dalam penelitiannya menyebutkan bahwa job stress berpengaruh negatif terhadap job satisfaction. Filliantoni et. al. (2019) dalam penelitiannya menyebutkan, stres kerja berpengaruh positif terhadap kepuasan kerja. Latifa Hanim (2016) dalam penelitiannya menyebutkan, stres kerja berpengaruh positif terhadap kepuasan kerja. Hipotesis pertama penelitian ini sebagai berikut:

H4: Terdapat pengaruh negatif job stress terhadap job satisfaction di kalangan wartawan

\section{Pengaruh work engagement terhadap job satisfaction}

Paramarta \& Darmayanti (2020) dalam penelitiannya menyebutkan, work engagement berpengaruh positif terhadap job satisfaction. Alzyoud (2019) dalam penelitiannya menyebutkan bahwa job satisfaction berpengaruh positif terhadap work engagement. Karyawan merasakan kepuasan dalam pekerjaannya karena merasa terlibat (engaged). Rai \& Maheshwari (2020) dalam studinya menemukan, work engagement berpengaruh positif terhadap job satisfaction. Yalabik et. al. (2017) dalam penelitiannya menemukan bahwa job satisfaction berpengaruh positif terhadap work engagement. Bayona et. al. (2020) dalam studinya menyebutkan, karyawan dengan work engagement tinggi memiliki job satisfaction yang lebih tinggi. Hipotesis pertama penelitian ini sebagai berikut: H5: Terdapat pengaruh positif work engagement terhadap job satisfaction di kalangan wartawan

\section{Pengaruh job stress terhadap job performance yang dimediasi work engagement}

Fontes et. al. (2019) dalam penelitiannya menyebutkan, job stress berpengaruh negatif terhadap work engagement. Wang \& Chen (2020) dalam penelitiannya menemukan, hubungan yang kurang baik dengan rekan kerja dapat mengurangi work engagement dan job performance. Inamizu \& Makishima (2018) dalam penelitiannya menyebutkan bahwa ada pengaruh positif antara job performance dan work engagement. Salleh et. al. (2020) dalam penelitiannya menemukan bahwa work load, time pressure, dan diskresi keterampilan yang merupakan dimensi dari job stress, berhubungan positif dengan job performance. Ahmad (2020) dalam penelitiannya menemukan bahwa job stress berpengaruh negatif terhadap job performance. Hipotesis pertama penelitian ini sebagai berikut:

H6: Terdapat pengaruh job stress terhadap job performance yang dimediasi work engagement di kalangan wartawan

\section{Pengaruh job stress terhadap job satisfaction yang dimediasi work engagement}

Amin et. al. (2018) dalam penelitiannya menemukan bahwa job stress berpengaruh negatif terhadap work engagement. Coetzee \& Villiers (2010) dalam penelitiannya menyebutkan, job stress yang dirasakan karyawan berpengaruh negatif terhadap work engagement dan orientasi karier mereka. Alzyoud (2019) dalam penelitiannya menyebutkan bahwa job satisfaction berpengaruh positif terhadap work engagement. Rai \& Maheshwari (2020) dalam penelitiannya menemukan, work engagement berpengaruh positif terhadap job satisfaction. Yalabik et. al. (2017) dalam penelitiannya menemukan bahwa job satisfaction berpengaruh positif terhadap work engagement. Hipotesis pertama penelitian ini sebagai berikut:

H7: Terdapat pengaruh job stress terhadap job satisfaction yang dimediasi work engagement di kalangan wartawan 


\section{METODE PENELITIAN}

Model penelitian dapat dilihat pda Gambar 1. Penelitian ini bersifat kuantitatif dengan menggunakan data primer dari hasil kuesioner yang dikirimkan kepada responden melalui Google Form dengan jumlah sampel sebanyak 340 responden. Dari 340 kuesioner yang dikirimkan, hanya 311 yang dapat diolah. Jumlah responden terbanyak adalah laki-laki sebanyak 205 orang (65.9\%), dengan sebaran usia terbanyak berada di rentang 35-40 tahun sebanyak 72 orang (23.2\%). Untuk domisili responden paling banyak berasal dari Jakarta sebesar 141 orang (45.3\%). Dilihat dari lama bekerja, mayoritas berada di kisaran 3-6 tahun sebanyak 76 orang $(24.4 \%)$.

Penelitian ini menggunakan satu variabel independen yaitu job stress di mana variabel ini diukur dengan menggunakan 13 item pernyataan dari Copenhagen Burnout Inventory (CBI) (Kristensen et. al., 2005), dua variabel dependen yaitu job performance yang diukur dengan menggunakan 18 item pernyataan dari Individual Work Performance Questionnaire (IWPQ) (Koopmans et. al., 2012) dan job satisfaction yang diukur dengan menggunakan 20 item pernyataan dari Minnesota Satisfaction Questionnaire (MSQ) (Martins \& Proença, 2014), serta variabel intervening yaitu work engagement yang diukur dengan menggunakan 17 item pernyataan dari Utrecht Work Engagement Score (UWES) (Schaufeli et. al., 2006). Metode analisis data menggunakan analisis deskriptif dengan ratarata dan standar deviasi. Sedangkan uji hipotesis menggunakan analisis structural equation modeling (SEM) dan pengolahan data menggunakan SPSS 21 dan AMOS 22.

Dari penelitian terdahulu, dapat kita lihat adanya proses berkesinambungan terbentuknya job performance dan job satisfaction di kalangan wartawan. Proses tersebut didahului dengan job stress yang berdampak pada work engagement, selanjutnya work engagement berdampak pada job performance dan job satisfaction. Setelah itu juga melihat bagaimana pengaruh job stress terhadap job performance dan job satisfaction, dan terakhir mengetahui pengaruh job stress terhadap job performance dan job satisfaction yang dimediasi work engagement. Penelitian ini akan meneliti bagaimana pengaruh masingmasing variabel terhadap variabel lainnya.

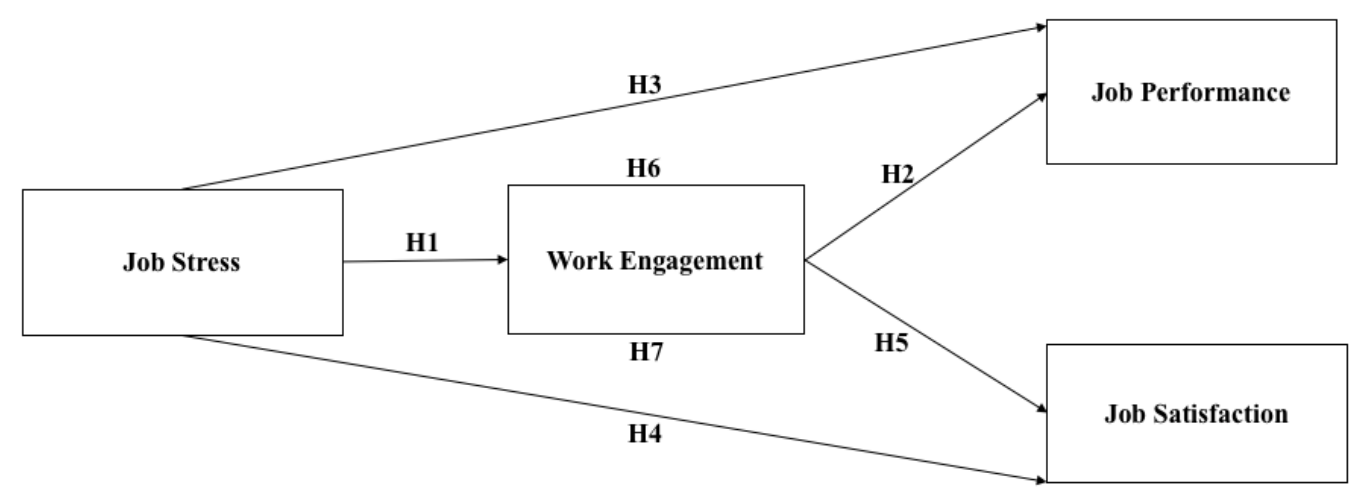

Gambar 1. Model Penelitian

Sumber: (Viswesvaran \& Ones, 2000; Martins \& Proença, 2014; Ghosh et. al., 2020; Amin et. al., 2018; Yongxing et. al., 2017; Coetzee \& Villiers, 2010; Najder \& Merecz-Kot, 2014; Salleh et. al., 2020; Singh et. al., 2019). 


\section{Uji Validitas dan Reliabilitas}

Tabel 1 menunjukkan hasil uji validitas. Jumlah factor loading disesuaikan dengan jumlah sampel yang ada. Sebanyak 311 responden menjadi sampel dalam penelitian ini. Apabila factor loading $>0.30$ maka item pernyataan dikatakan valid. Apabila factor loading $<0.30$ maka item pernyataan dikatakan tidak valid.

Tabel 1. Hasil Uji Validitas

\begin{tabular}{|l|c|c|}
\hline \multicolumn{1}{|c|}{ Variabel } & Jumlah Item Pernyataan & Item Pernyataan Valid \\
\hline Job Stress & 13 & 13 \\
\hline Work Engagement & 17 & 17 \\
\hline Job Performance & 18 & 18 \\
\hline Job Satisfaction & 20 & 20 \\
\hline
\end{tabular}

Sumber: Data Diolah

Tabel 2 menunjukkan hasil uji reliabilitas. Setelah semua item pernyataan dinyatakan valid, kemudian dilanjutkan dengan uji reliabilitas untuk mengetahui tingkat konsistensi alat ukur. Pengukuran reliabilitas menggunakan construct reliability (CR) dengan ketentuan jika nilai $>0.6$ maka item pernyataan dalam kuesioner dikatakan reliabel. Sebalikinya jika nilai $<0.6$ maka item pernyataan dalam kuesioner dikatakan tidak reliabel.

Tabel 2. Hasil Uji Reliabilitas

\begin{tabular}{|c|c|c|}
\hline Konstruk & Construct Reliability & Keterangan \\
\hline Job Stress & 0.9106558 & Reliabel \\
\hline Work Engagement & 0.8416685 & Reliabel \\
\hline Job Satisfaction & 0.7833844 & Reliabel \\
\hline Job Performance & 0.7065341 & Reliabel \\
\hline
\end{tabular}

Sumber: Data Diolah

\section{Uji Goodness of Fit}

Uji Goodness of Fit dapat dilihat pada Tabel 3 dan Gambar 2. Selanjutnya dilakukan uji Goodness of Fit sehingga jumlah item pernyataan untuk masing-masing variabel berjumlah seperti tabel di bawah ini:

Tabel 3. Hasil Uji Goodness of Fit

\begin{tabular}{|c|c|c|}
\hline Kriteria & Hasil & Kesimpulan \\
\hline p-value & 0.000 & Tidak memenuhi \\
\hline RMSEA & 0.062 & Memenuhi \\
\hline GFI & 0.867 & Marginal fit \\
\hline AGFI & 0.839 & Marginal fit \\
\hline TLI & 0.895 & Good fit \\
\hline CFI & 0.906 & Marginal fit \\
\hline NFI & 0.842 & Marginal fit \\
\hline
\end{tabular}

Sumber: Data Diolah 


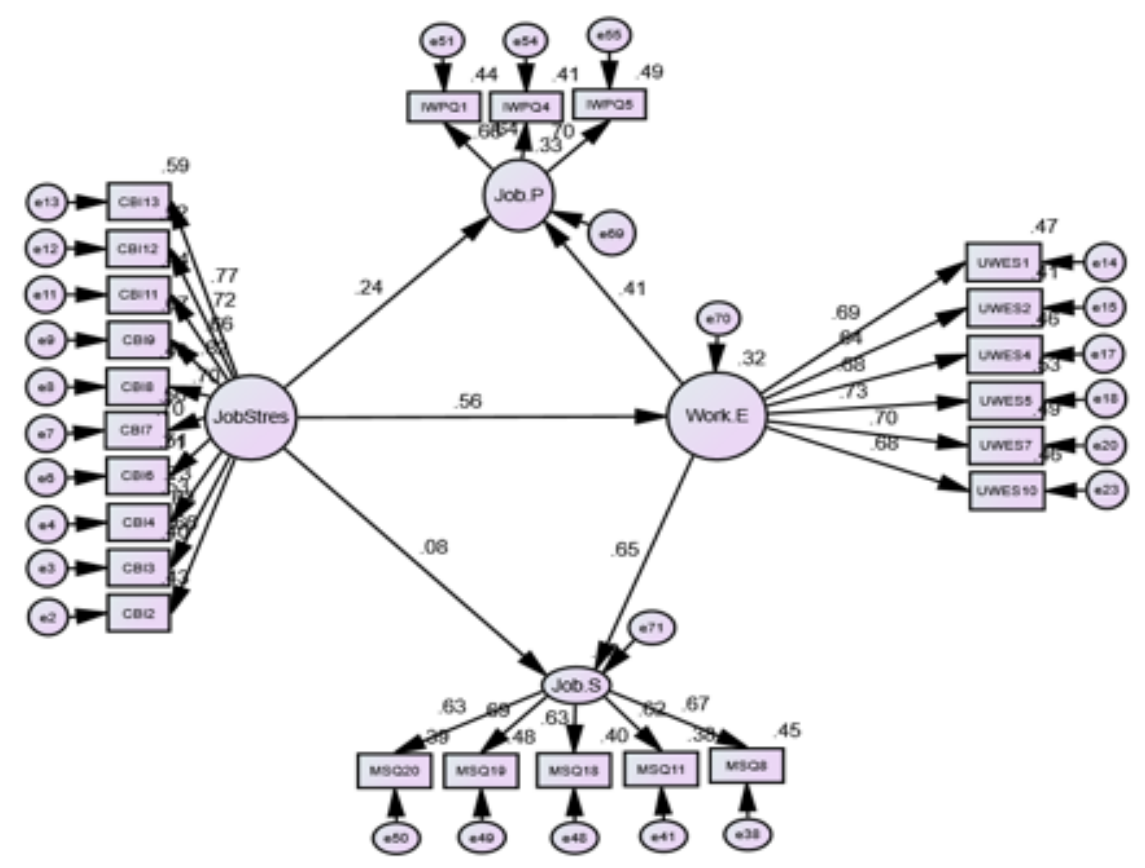

Gambar 2. Fit Full SEM

\section{HASIL PENELITIAN DAN PEMBAHASAN}

Berdasarkan kerangka berpikir yang telah diuraikan, analisis structural model dan Goodness of Fit, hal ini menjadi landasan untuk melakukan uji hipotesis dengan tingkat signifikansi $\alpha($ alpha $)=0.05$. Hasil uji hipotesis (Tabel 4) sebagai berikut:

Tabel 4. Hasil Uji Hipotesis

\begin{tabular}{|c|c|c|c|c|}
\hline Hipotesis & Keterangan & Estimate & $\mathbf{P}$ & Hasil \\
\hline $\begin{array}{l}\text { Terdapat pengaruh job stress terhadap } \\
\text { work engagement }(\mathbf{H 1})\end{array}$ & $\mathrm{JS} \rightarrow \mathrm{WE}$ & 0.392 & 0.000 & Didukung \\
\hline $\begin{array}{l}\text { Terdapat pengaruh work engagement } \\
\text { terhadap job performance di kalangan } \\
\text { wartawan (H2) }\end{array}$ & $\mathrm{WE} \rightarrow \mathrm{JP}$ & 0.383 & 0.000 & Didukung \\
\hline $\begin{array}{l}\text { Terdapat pengaruh job stress terhadap } \\
\text { job performance di kalangan wartawan } \\
\text { (H3) }\end{array}$ & $\mathrm{JS} \rightarrow \mathrm{JP}$ & 0.155 & 0.004 & Didukung \\
\hline $\begin{array}{l}\text { Terdapat pengaruh job stress terhadap } \\
\text { job satisfaction di kalangan wartawan } \\
\text { (H4) }\end{array}$ & $\mathrm{JS} \rightarrow \mathrm{JSa}$ & 0.055 & 0.286 & $\begin{array}{l}\text { Tidak } \\
\text { Didukung }\end{array}$ \\
\hline $\begin{array}{l}\text { Terdapat pengaruh work engagement } \\
\text { terhadap job satisfaction di kalangan } \\
\text { wartawan }(\mathbf{H 5})\end{array}$ & $\mathrm{WE} \rightarrow \mathrm{JSa}$ & 0.672 & 0.000 & Didukung \\
\hline $\begin{array}{l}\text { Terdapat pengaruh job stress terhadap } \\
\text { job performance yang dimediasi work } \\
\text { engagement di kalangan wartawan (Ho) }\end{array}$ & $\mathrm{JS} \rightarrow \mathrm{WE} \rightarrow \mathrm{JP}$ & 0.229 & 0.000 & Didukung \\
\hline $\begin{array}{l}\text { Terdapat pengaruh job stress terhadap } \\
\text { job satisfaction yang dimediasi work } \\
\text { engagement di kalangan wartawan }(\mathbf{H} 7)\end{array}$ & $\mathrm{JS} \rightarrow \mathrm{WE} \rightarrow \mathrm{JSa}$ & 0.365 & 0.000 & Didukung \\
\hline
\end{tabular}

Sumber: Data Diolah 
Pada uji hipotesis 1 didapatkan nilai estimasi 0.392 dan nilai p-value 0.00 lebih kecil dari nilai alpha 0.05 sehingga $\mathrm{H} 1$ tidak didukung, di mana terdapat pengaruh negatif antara job stress terhadap work engagement tapi tidak signifikan. Artinya, ada pengaruh positif walau sangat kecil jumlahnya, karena fakta yang ditemukan dalam penelitian menunjukkan, jika job stress tinggi, karyawan malah makin terlibat (engaged) dengan pekerjaan. Berdasarkan pengamatan di lapangan, ketika wartawan stres, wartawan justru makin terlibat dengan pekerjaannya, di mana mereka bersemangat, berusaha keras, fokus, hingga lupa dengan keadaan sekitarnya untuk secepatnya menyelesaikan pekerjaan. Hal ini didasari oleh rasa profesionalisme dan tanggung jawab dalam pekerjaannya. Hasil penelitian ini didukung Vandiya \& Etikariena (2018), yang melakukan penelitian terhadap 200 karyawan swasta di Jakarta, yang rata-rata bekerja di dalam ruangan melakukan tugas-tugas administrasi, memiliki rentang usia 25-49 tahun, dan lulus program sarjana. Disebutkan bahwa job stress berpengaruh negatif tapi tidak signifikan terhadap work engagement. Hasil penelitian ini tidak didukung oleh para ahli yang menyatakan bahwa stres berpengaruh negatif dengan work engagement, di mana work engagement karyawan akan turun saat stres tinggi (Moura et. al., 2014; Fontes et. al. 2019; Motamedzade et. al., 2019; Amin et. al., 2018). Coetzee \& Villiers (2010) menyatakan, sumber job stress yang dirasakan karyawan berpengaruh signifikan dengan work engagement dan orientasi karier.

Pada uji hipotesis 2 didapatkan nilai estimasi 0.383 dan nilai p-value 0.00 lebih kecil dari nilai alpha 0.05 sehingga $\mathrm{H} 2$ didukung. Dapat dikatakan bahwa work engagement berpengaruh positif dan signifikan terhadap job performance. Hal ini dapat diartikan bahwa wartawan yang merasakan keterlibatan tinggi terhadap pekerjaannya secara otomatis kinerjanya juga akan meningkat. Temuan di lapangan menunjukkan, wartawan yang memiliki work engagement yang baik diliputi semangat, passion, dedikasi, dan kecintaan yang kuat terhadap pekerjaannya. Hal tersebut secara otomatis mempengaruhi job performance mereka. Hasil penelitian ini didukung oleh para ahli yang mengatakan bahwa work engagement berpengaruh positif terhadap job performance, di mana ketika work engagement meningkat, job performance juga meningkat (Inamizu \& Makishima, 2018; Wang \& Chen, 2020; Herliani \& Sagala, 2021; Naveed Jabbar et. al., 2019; Bakker et. al., 2012; Jackson, 2014; Suryanthini, 2020).

Dalam uji hipotesis 3 didapatkan nilai estimasi 0.155 dan nilai p-value 0.004 lebih kecil dari nilai alpha 0.05 sehingga $\mathrm{H} 3$ didukung, di mana job stress berpengaruh negatif dan signifikan terhadap job performance. Dapat diartikan bahwa wartawan yang mengalami stres tidak akan mendapatkan performansi yang baik. Fakta yang ditemukan di lapangan menunjukkan, beban kerja dan demand dari atasan yang datang bertubi-tubi menyebabkan wartawan stres. Jika stres tersebut tidak bisa dikelola dengan baik, maka akan mengganggu produktivitas dan kinerja wartawan. Akibatnya, output yang dihasilkan tidak akan maksimal. Penelitian ini didukung oleh pendapat sejumlah ahli yang menyebutkan terdapat pengaruh negatif antara job stress terhadap job performance, di mana ketika job stress meningkat maka job performance turun (Herliani \& Sagala, 2021; Ahmad, 2020). Job demand, job control, work load, tekanan waktu, dan ambiguitas peran berpengaruh signifikan terhadap job performance (Salleh et. al., 2020; Basit \& Hassan, 2017; Gharib et. al., 2016). Berbeda dengan hasil penelitian di atas, Suryanthini (2020) menyatakan, job stress tidak memengaruhi job performance. Dalam penelitian yang dilakukan terhadap 106 responden di perusahaan di Denpasar, Bali, disebutkan bahwa hasil penelitian yang dilakukan ini tidak dapat digunakan untuk menggeneralisasi bahwa job stress berpengaruh negatif terhadap job performance karyawan di perusahaan lainnya. Disebutkan juga bahwa "job stress dapat menciptakan keunggulan kompetitif bagi perusahaan. Namun jika stres yang dialami karyawan terlalu tinggi, kinerja karyawan dapat terganggu." 
Dalam uji hipotesis 4 didapatkan nilai estimasi 0.055 dan nilai p-value 0.286 lebih besar dari nilai alpha 0.05 sehingga $\mathrm{H} 4$ tidak didukung, di mana terdapat pengaruh positif dan tidak signifikan job stress terhadap job satisfaction. Temuan di lapangan menunjukkan, ketika wartawan mengalami job stress, mereka malah semakin puas dengan pekerjaannya. Berdasarkan temuan di lapangan, ketika wartawan stres dengan pekerjaannya, mereka semakin giat bekerja, bersemangat, dan bertanggung jawab untuk segera menyelesaikan pekerjaannya sehingga hasil kerjanya - yang berupa artikel berita, bisa diterbitkan di media. Tekanan atau stres yang berhasil dilalui wartawan akan memunculkan rasa kepuasan dan kebanggan dalam diri wartawan, apalagi ditambah dengan dukungan sosial - berupa apresiasi dari rekan kerja atau atasan yang memberikan reward berupa ajakan makan siang atau minum kopi di kafe. Hasil penelitian ini didukung oleh Latifa Hanim (2016) yang menyebutkan, stres kerja berpengaruh positif terhadap kepuasan kerja pada karyawan bagian hull construction di PT Dok dan Perkapalan Surabaya. Penelitian sama oleh Filliantoni et. al. (2019) menyebutkan, stres kerja berpengaruh positif terhadap kepuasan kerja pada karyawan di dealer Indomobil Nissan Datsun Solo Baru. Hasil penelitian ini tidak didukung oleh pendapat beberapa ahli yang menyebutkan bahwa job stress berpengaruh negatif terhadap job satisfaction. Semakin tinggi job stress yang dialami pekerja, semakin rendah job satisfaction yang dirasakan. Semakin rendah stres yang dirasakan karyawan, semakin tinggi job satisfaction yang dialami (Rizwan et. al., 2014; Paramarta \& Darmayanti, 2020; Angreni \& Ardana, 2020; Jehangir et. al., 2011; Orgambídez-Ramos et. al., 2014; Singh et. al., 2019).

Dalam uji hipotesis 5 didapatkan nilai estimasi 0.672 dan nilai p-value 0.000 lebih kecil dari nilai alpha 0.05 sehingga $\mathrm{H} 5$ didukung, di mana work engagement berpengaruh positif dan signifikan terhadap job satisfaction. Dapat diartikan bahwa wartawan yang memiliki semangat, dedikasi, dan absorpsi dalam pekerjaannya setiap hari cenderung mendapatkan job satisfaction yang tinggi. Ketika wartawan melakukan tugas-tugas jurnalistik, mereka dipenuhi energi yang kuat, bersemangat, berdedikasi tinggi, penuh passion, dan rasa kebanggaan terhadap profesinya. Rasa-rasa positif semacam ini - yang merupakan dimensi dari work engagement, ditambah dukungan sosial dari rekan kerja atau atasan yang selalu memberikan dorongan dan dukungan kepada wartawan secara otomatis akan memunculkan job satisfaction. Hasil penelitian ini didukung oleh pendapat para ahli yang menyebutkan bahwa work engagement berpengaruh positif terhadap job satisfaction (Paramarta \& Darmayanti, 2020; Alzyoud, 2019; Rai \& Maheshwari, 2020; Yalabik et. al., 2017; Ghosh et. al., 2020).

Dalam uji hipotesis 6 didapatkan nilai estimasi 0.229 dan nilai p-value 0.000 lebih kecil dari nilai alpha 0.05 sehingga H6 didukung, di mana terdapat pengaruh tidak langsung positif dan signifikan antara job stress terhadap job performance yang dimediasi work engagement. Ketika wartawan mengalami job stress, hingga membuat mereka merasa lelah dan frustrasi, hal tersebut secara tidak langsung akan berpengaruh pada job performance. Semangat, dedikasi, kemampuan \& keterampilan, passion, dan kecintaan wartawan terhadap pekerjaan sehari-hari, yang dibarengi dengan semangat profesionalisme dan rasa tanggung jawab kepada keluarga, selama ini menjadi alasan wartawan untuk tetap bekerja. Keterlibatakan terhadap pekerjaan (work engagement) dan kemampuan mereka mengelola stres dengan baik, membuat job performance tetap terjaga dan tidak mengalami penurunan. Work engagement berhasil menjadi mediasi antara job stress dan job performance. Temuan ini didukung oleh Fontes et. al. (2019) yang menyebutkan, job stress berpengaruh negatif terhadap work engagement. Pekerja yang tingkat stresnya rendah memiliki work engagement yang baik. Pekerja yang tingkat stresnya tinggi, kurang memiliki work engagement yang baik. Wang \& Chen (2020) dalam penelitian menemukan bahwa work engagement 
berpengaruh positif dengan job performance. Inamizu \& Makishima (2018) dalam penelitiannya menyebutkan bahwa ada pengaruh positif antara job performance dan work engagement.

Dalam uji hipotesis 7 didapatkan nilai estimasi 0.365 dan nilai p-value 0.000 lebih kecil dari nilai alpha 0.05 sehingga $\mathrm{H} 7$ didukung, di mana terdapat pengaruh tidak langsung positif dan signifikan antara job stress terhadap job satisfaction yang dimediasi work engagement. Ketika wartawan mengalami job stress, hingga membuat mereka merasa lelah dan frustrasi, hal tersebut secara tidak langsung akan berpengaruh pada job satisfaction. Semangat, dedikasi, kemampuan \& keterampilan, passion, dan kecintaan wartawan terhadap pekerjaan sehari-hari, yang dibarengi dengan semangat profesionalisme dan rasa tanggung jawab kepada keluarga, selama ini menjadi alasan wartawan untuk tetap bekerja. Keterlibatan terhadap pekerjaan (work engagement), kemampuan mereka mengelola stres dengan baik, dan dukungan sosial dari lingkungan kerja dan keluarga membuat job satisfaction tetap terjaga dan tidak mengalami penurunan. Work engagement berhasil menjadi mediasi antara job stress dan jobsatisfaction. Penelitian ini didukung Motamedzade et. al. (2019) yang menyebutkan, work engagement berpengaruh negatif pada job stress. Amin et. al. (2018) menemukan bahwa job stress berpengaruh negatif terhadap work engagement. Coetzee \& Villiers (2010) dalam penelitian menemukan, sumber job stress yang dirasakan karyawan berpengaruh negatif terhadap work engagement dan orientasi karier mereka. Alzyoud (2019) menyebutkan bahwa job satisfaction berpengaruh positif terhadap work engagement. Rai \& Maheshwari (2020) menemukan, work engagement berpengaruh positif terhadap job satisfaction. Yalabik et. al. (2017) menemukan, job satisfaction berpengaruh positif terhadap work engagement. Ghosh et. al. (2020) menemukan bahwa work engagement berpengaruh positif terhadap job satisfaction. Rizwan et. al. (2014) menyatakan, job stress berpengaruh negatif terhadap job satisfaction.

\section{PENUTUP \\ Simpulan}

Hasil penelitian ini dapat disimpulan bahwa ketika job stress tinggi, work engagement wartawan juga tinggi; ketika work engagement wartawan naik, job performance wartawan juga naik; ketika wartawan mengalami stres, maka job performance akan turun; ketika tingkat stress wartawan tinggi, kepuasan mereka terhadap pekerjaan juga tinggi; ketika wartawan merasakan work engagement, mereka juga merasakan job satisfaction; peran work engagement sebagai mediasi antara job stress dan job performance tercapai dengan baik; dan terakhir, peran work engagement sebagai mediasi job stress dan job satisfaction tercapai dengan baik

\section{Implikasi Manajerial}

Disarankan agar manajemen perusahaan media, terutama atasan langsung wartawan - seperti redaktur, redaktur pelaksana, dan pemimpin redaksi, memberikan tugas/beban kerja yang sesuai dengan kemampuan wartawan serta mengurangi demand yang berlebihan kepada wartawan guna menghindari munculnya job stress terhadap wartawan. Selain itu, perusahaan media disarankan untuk tidak mewajibkan wartawan men-tap mesin absensi tool yang digunakan sebagai absensi dan mengukur key performance indicator (KPI) yang dijadikan landasan sebagai pemberian remunerasi kepada wartawan setiap bulannya. Tool yang digunakan untuk mengukur/menyamakan cara kerja wartawan seperti karyawan pada umumnya (non-redaksi) tidak bisa diterapkan pada wartawan karena kehadiran wartawan bukan ditentukan oleh absen di mesin, tapi pada berapa banyak artikel yang ditulis pada hari itu. Manajemen perusahaan media disarankan melakukan evaluasi melalui tes atau 
assessment terhadap setiap wartawan di masing-masing desk setiap satu tahun sekali guna mengetahui apakah wartawan tersebut cocok berada di desk tersebut sehingga hal ini dapat mengurangi tingkat stres yang dialami wartawan. Untuk menghindari kemungkinan tersebut, disarankan juga melakukan rolling pekerjaan setiap satu tahun sekali agar wartawan bisa beradaptasi dengan pekerjaan (desk) yang berbeda. Terakhir, disarankan kepada manajemen perusahaan media memberikan reward kepada wartawan berupa kenaikan gaji, kesempatan untuk berlibur, cuti di luar cuti tahunan, bonus/insentif, kesempatan melanjutkan pendidikan sesuai dengan bidangnya, mengikuti pelatihan, atau memberikan opportunity lainnya untuk meredam job stress yang dirasakan wartawan.

\section{Saran untuk Penelitian Selanjutnya}

Untuk penelitian selanjutnya disarankan melakukan penelitian dengan tema dan objek yang sama, tapi variabel yang berbeda. Bisa ditambahkan variabel baru seperti disiplin kerja, lingkungan kerja, motivasi, dan budaya. Selain itu juga disarankan untuk melakukan penelitian dengan objek sama dengan mengambil sampel wartawan yang bekerja di beberapa kota besar di Indonesia selain di Jakarta. Saran berikutnya untuk penelitian selanjutnya adalah menggunakan teknik analisis data yang berbeda selain AMOS, misalkan Smart PLS, Metlab, atau lainnya agar memberikan hasil yang berbeda.

\section{Keterbatasan Penelitian}

Penelitian ini hanya meneliti wartawan yang bekerja dan berada di Jakarta dan belum menyentuh wartawan di beberapa kota besar lainnya di Indonesia. Melihat kondisi pandemi COVID-19 seperti saat ini, sepertinya belum memungkinkan untuk melakukan penelitian secara lebih menyeluruh terhadap wartawan di beberapa kota besar Indonesia guna mendapatkan hasil lebih maksimal. Selain itu, pengumpulan data hanya dilakukan dengan penyebaran kuesioner melalui Internet dengan Google Form. Padahal ada langkah lain yang bisa dilakukan, termasuk melakukan wawancara langsung dengan objek penelitian atau melakukan observasi langsung ke tempat/rumah objek penelitian bekerja/tinggal. Situasi pandemi COVID-19 membuat peneliti sedikit kesulitan untuk melakukan observasi langsung.

\section{DAFTAR PUSTAKA}

Abu-Shamaa, R., Wafaa A Al-Rabayah, \& Khasawneh, R. T. (2016). The Effect of Job Satisfaction and Work Engagement on Organizational Commitment. The IUP Journal of Organizational Behavior, 4, 7-27.

Ahmad, S. (2020). Impact of Job Stress on Employee Job Performance : A Study of Developmental Sector of Chitral District International Journal of Social Science Archives Impact of Job Stress on Employee Job Performance: A Study of Developmental Sector of Chitral District. June 2019.

Alzyoud, A. (2019). Job Satisfaction and Work Engagement. VI(November 2018), 125-139.

Amin, M., Khattak, A. Z., \& Khan, M. Z. (2018). Effects of Job Stress on Employee Engagement and Organizational Commitment: a Study on Employees of Emergency Rescue Service Rescue 1122 District Peshawar. City University Research Journal, 8(2), 200-208.

Angreni, D. D., \& Ardana, I. K. (2020). The Effect of Work Motivation and Work Stress on Job Satisfaction with Emotional Intelligence as a Moderated Variables in SV. Pondok Antik. American Journal of Humanities and Social Sciences Research, 4(3), 418-424.

Bakker, A. B., \& Demerouti, E. (2008). Towards a model of work engagement. Career Development International, 13(3), 209-223. https://doi.org/10.1108/13620430810870476 
Bakker, A. B., Tims, M., \& Derks, D. (2012). Proactive personality and job performance: The role of job crafting and work engagement. Human Relations, 65(10), 1359-1378. https://doi.org/10.1177/0018726712453471

Basit, A., \& Hassan, Z. (2017). Impact of Job Stress on Employee Performance. International Journal of Accounting, Business \& Management, 5(2), 13-33.

Bayona, J. A., Caballer, A., \& Peiró, J. M. (2020). The relationship between knowledge characteristics' fit and job satisfaction and job performance: The mediating role of work engagement. Sustainability (Switzerland), 12(6). https://doi.org/10.3390/su12062336

Chen, J. C., Silverthorne, C., \& Hung, J. Y. (2006). Organization communication, job stress, organizational commitment, and job performance of accounting professionals in Taiwan and America. Leadership \& Organization Development Journal, 27(4), 242-249. https://doi.org/10.1108/01437730610666000

Coetzee, M., \& Villiers, M. De. (2010). Sources of job stress, work engagement and career orientations of employees in a South African fi nancial institution. Southern African Business Review, 14(1), 27-58.

Filliantoni, B., Hartono, S., \& Sudarwati. (2019). Pengaruh Disiplin Kerja Dan Stres Kerja Terhadap Kinerja Karyawan Melalui Mediasi Kepuasan Kerja Pada Karyawan Indomobil Nissan-Datsun Solobaru ). Edunomika, 03(01), 119-130.

Fontes, L., Gonçalves, A., Gomes, A. R., \& Simães, C. (2019). Stress and work engagement in health professionals. Studies in Systems, Decision and Control, 202(January), 553-561. https://doi.org/10.1007/978-3-030-14730-3_59

Gharib, M. N., Jamil, S. A., Ahmad, M., \& Ghouse, S. (2016). The impact of job stress on job performance: A case study on academic staff at dhofar university. International Journal of Economic Research, 13(1), 21-33.

Ghosh, P., Jawahar, I. M., \& Rai, A. (2020). Do men and women experience work engagement and job satisfaction to the same extent in collectivistic, patriarchal societies? International Journal of Manpower, 41(1), 52-67. https://doi.org/10.1108/IJM-11-2018-0378

Hafeez, S. (2018). Case Report The Impact of Job Stress on Performance of Employees : A Study of Social Security Hospital of District Okara \& Sahiwal. Journal of Neuropsychology \& Stress Management, 12(3), 4-12.

Herliani, V. T., \& Sagala, E. J. (2021). Pengaruh Stres Kerja, Komitmen Organisasi Dan Work Engagement Terhadap Kinerja Karyawan Di Dinas Kebakaran Dan Penanggulangan Bencana Kota Bandung. EProceedings of Management, 7(3), 5613-5620.

Inamizu, N., \& Makishima, M. (2018). Job performance explains work engagement: Curvilinear relations between the two. Annals of Business Administrative Science, 17(4), 159-169. https://doi.org/10.7880/abas.0180712a

Jackson, L. J. (2014). The work engagement and job performance relationship: Exploring the mediating effect of trait emotional intelligence. 1-60.

Jehangir, M., Kareem, N., Khan, A., Jan, M., \& Soherwardi, S. (2011). Effects of job stress on job performance and job satisfaction. Interdisciplinary Journal of Contemporary Research in Business, 3(7), 453-465.

Koopmans, L., Bernaards, C., Hildebrandt, V., Van Buuren, S., Van Der Beek, A. J., \& de Vet, H. C. w. (2012). Development of an individual work performance questionnaire. International Journal of Productivity and Performance Management, 62(1), 6-28. https://doi.org/10.1108/17410401311285273

Kristensen, T. S., Borritz, M., Villadsen, E., \& Christensen, K. B. (2005). The Copenhagen Burnout Inventory: A new tool for the assessment of burnout. Work and Stress, 19(3), 192-207. https://doi.org/10.1080/02678370500297720

Latifa Hanim, M. (2016). Pengaruh Stres Kerja Terhadap Kepuasan Kerja Serta Dampaknya Pada Kinerja Karyawan Hull Construction Di Pt. Dok Dan Perkapalan Surabaya. Jurnal Ilmu Manajemen (JIM), 4(3), 1-10.

Martins, H., \& Proença, M. T. (2014). Minnesota satisfaction questionnaire: psychometric properties and validation in a population of portuguese hospital workers. Investigação e Intervenção Em Recursos Humanos, 3. https://doi.org/10.26537/iirh.v0i3.1825 
Motamedzade, M., Asghari, M., Basati, M., Safari, H., Afshari, M., \& Abbassinia, M. (2019). The relationship between Work Engagement and Job Stress among Emergency Technicians of Markazi Province, Iran, in 2015. Iranian Journal of Health, Safety \& Environment, 6(2), 12591266.

Moura, D., Orgambídez-Ramos, A., \& Gonçalves, G. (2014). Role stress and work engagement as antecedents of job satisfaction: Results from Portugal. Europe's Journal of Psychology, 10(2), 291-300. https://doi.org/10.5964/ejop.v10i2.714

Muala, I. Al. (2017). Job Stress in Journalism: Interaction between Organisational Support and Job Demands-Resources Model. Journal of Management and Sustainability, 7(4), 150. https://doi.org/10.5539/jms.v7n4p150

Najder, A., \& Merecz-Kot, D. (2014). Stres zawodowy a ryzyko psychospołeczne w grupie dziennikarzy. Medycyna Pracy, 65(1), 85-97. https://doi.org/10.13075/mp.5893.2014.008

Naveed Jabbar, M., Riaz, A., Nawaz, M., Abbas Bhatti, G., \& Choudhary, A. (2019). "Does optimism and work engagement matter to improve job Performance? An empirical study View project DOES OPTIMISM AND WORK ENGAGEMENT MATTER TO IMPROVE JOB PERFORMANCE? AN EMPIRICAL STUDY. International Journal of Information, Business and Management, 11(4).

Orgambídez-Ramos, A., Borrego-Alés, Y., \& Mendoza-Sierra, I. (2014). Role stress and work engagement as antecedents of job satisfaction in Spanish workers. Journal of Industrial Engineering and Management, 7(1), 360-372. https://doi.org/10.3926/jiem.992

Paramarta, W. A., \& Darmayanti, N. P. K. (2020). Employee Engagement Dan Stress Kerja Pengaruhnya Terhadap Kepuasan Kerja Dan Turnover Intention di Aman Villas Nusa Dua Bali. Widya Manajemen, 2(1), 60-79. https://doi.org/10.32795/widyamanajemen.v2i1.550

Pollak, A., Chrupała-Pniak, M., Rudnicka, P., \& Paliga, M. (2017). Work Engagement - A Systematic Review of Polish Research. Polish Psychological Bulletin, 48(2), 175-187. https://doi.org/10.1515/ppb-2017-0021

Rai, A., \& Maheshwari, S. (2020). Exploring the mediating role of work engagement between the linkages of job characteristics with organizational engagement and job satisfaction. Management Research Review, 44(1), 133-157. https://doi.org/10.1108/MRR-10-2019-0442

Ramalho Luz, C. M. D., Luiz de Paula, S., \& de Oliveira, L. M. B. (2018). Organizational commitment, job satisfaction and their possible influences on intent to turnover. Revista de Gestão, 25(1), 84-101. https://doi.org/10.1108/rege-12-2017-008

Ramos-Villagrasa, P. J., Barrada, J. R., Fernandez-del-Rio, E., \& Koopmans, L. (2019). Assessing Job Performance Using Brief Self-report Scales: The Case of the. Journal of Work and Organizational Psychology, 35(3), 195-205.

Rizwan, M., Waseem, A., \& Bukhari, S. A. (2014). Antecedents of Job Stress and its impact on Job Performance and Job Satisfaction. International Journal of Learning and Development, 4(2), 187-203. https://doi.org/10.5296/ijld.v4i2.6097

Ryu, K. (2020). The impact of organizational ethical climate on organizational commitment and job performance: An economic ethics analysis of Japanese-funded manufacturing enterprises in China. In The Impact of Organizational Ethical Climate on Organizational Commitment and Job Performance: An Economic Ethics Analysis of Japanese-funded Manufacturing Enterprises in China. https://doi.org/10.1007/978-981-15-2813-2

Salleh, J., Noor, N. M., Nabilah, A., Rafil, A., Hafizon, N., \& Dealwis, C. (2020). The Relationship Between Employees' Job Stress and Job Performance: a Case Study At Pejabat Residen Bahagian Samarahan, Sarawak. March, 59-69.

Schaufeli, W. B. (2012). Work Engagement. What Do We Know and Where Do We Go? Romanian Journal of Applied Psychology, 14(1), 3-10.

Schaufeli, W. B., Bakker, A. B., \& Salanova, M. (2006). The measurement of work engagement with a short questionnaire: A cross-national study. Educational and Psychological Measurement, 66(4), 701-716. https://doi.org/10.1177/0013164405282471

Singh, M. M., Amiril, M., \& Sabbarwal, S. (2019). Role of Job Stress on Job Satisfaction. International Journal of Management Studies, VI(4), 57. https://doi.org/10.18843/ijms/v6i4/08

Suryanthini, P. M. (2020). The Influence of Job Stress and Employee Engagement to Organizational 
Commitment and Employee Performance (Study on PT. Biseka Denpasar). International Journal of Contemporary Research and Review, 11(08), 21836-21845. https://doi.org/10.15520/ijcrr.v11i08.833

Vandiya, V., \& Etikariena, A. (2018). Stres Kerja dan Keterikatan Kerja pada Karyawan Swasta: Peran Mediasi Kesejahteraan di Tempat Kerja. Journal Psikogenesis, 6(1), 19-34. https://doi.org/10.24854/jps.v6i1.648

Viswesvaran, C., \& Ones, D. S. (2000). Perspectives on Models of Job Performance. International Journal of Selection and Assessment, 8(4), 216-226. https://doi.org/10.1111/1468-2389.00151

Wang, C.-H., \& Chen, H.-T. (2020). Relationships among workplace incivility, work engagement and job performance. Journal of Hospitality and Tourism Insights, 3(4), 415-429. https://doi.org/10.1108/jhti-09-2019-0105

Whitman, D. S., Van Rooy, D. L., \& Viswesvaran, C. (2010). Satisfaction, citizenship behaviors, and performance in work units: A meta-analysis of collective construct relations. Personnel Psychology, 63(1), 41-81. https://doi.org/10.1111/j.1744-6570.2009.01162.x

Yalabik, Z. Y., Rayton, B. A., \& Rapti, A. (2017). Facets of job satisfaction and work engagement. Evidence-Based HRM, 5(3), 248-265. https://doi.org/10.1108/EBHRM-08-2015-0036

Yongxing, G., Hongfei, D., Baoguo, X., \& Lei, M. (2017). Work engagement and job performance: The moderating role of perceived organizational support. Anales de Psicologia, 33(3), 708713. https://doi.org/10.6018/analesps.33.3.238571 